
experimental planning. Horticultura Brasileira 26:035-039.

\title{
Heterogeneity index of zucchini yield on a protected environment and experimental planning
}

\author{
Sandra Feijó; Lindolfo Storck; Alessandro Dal’Col Lúcio; Sidinei José Lopes; Danton C Garcia; \\ Ricardo H Carpes
}

UFSM - Dep ${ }^{\text {to }}$ Fitotecnia, 97105-900 Santa Maria-RS; lindolfo@smail.ufsm.br

\begin{abstract}
The objectives of this work were to assess zucchini heterogeneity index and fruit weight at different harvest frequencies for plants grown on a protected environment; to estimate the optimum plot size; and to determine the least significant difference among treatments, varying plot size and replication number. Plants of cultivar Caserta were grown in a plastic greenhouse, using spaces of $0.80 \mathrm{x}$ 1.00 among plants and lines, respectively. The following harvest frequencies were studied: fruits harvested daily, (1) at 10:00, (2) at 10:00 and 18:00, (3) at 8:00, 10:00, 12:00, 14:00, 16:00 and 18:00 h and; (4) fruits harvested every other day, at 18:00 h. Twenty-seven harvests were carried out, collecting fruits larger than $0.15 \mathrm{~m}$. Plots were planned with 1, 2, 3, and 6 plants per row. Heterogeneity index was estimated according to Smith's method and, the optimum plot size, according to modified maximum curvature method. Fruit yield per plant gradually increased reaching a maximum at the $15^{\text {th }}$ harvest. Total yield was of 3214, 3124, 3928 and 3248 g plant $^{-1}$, respectively, at the harvest frequencies 1, 2, 3 and 4, with no significant differences among them. The heterogeneity index in the plastic greenhouse was nearly zero. The use of smaller plots combined with a larger number of replications increased the experimental accuracy. Although optimum plot size to assess total fruit yield varied between one and seven plants, depending on the harvest frequency, plots with three plants per row plots, with six replications, were the most appropriate design, allowing detecting a least significant difference among treatments equal to $76 \%$ of the mean.
\end{abstract}

Keywords: Cucurbita pepo, experimental accuracy, plot size, harvest frequency.

\begin{abstract}
RESUMO
Índice de heterogeneidade da produção de abobrinha italiana em ambiente protegido e planejamento experimental

Os objetivos deste trabalho foram avaliar o índice de heterogeneidade para diferentes freqüências de colheita e peso de frutos de abobrinha italiana produzida em ambiente protegido; estimar o tamanho ótimo de parcela e determinar a diferença mínima significativa entre tratamentos, variando o tamanho de parcela e o número de repetições. Plantas da cultivar Caserta foram instaladas em estufa plástica com espaçamento de 0,80 x 1,0 m entre plantas e linhas, respectivamente, Foram aplicadas as freqüências de colheita: frutos colhidos diariamente, (1) às 10 horas, (2) às 10 e 18 horas, (3) às 8, 10, 12, 14, 16 e 18 horas e; (4) frutos colhidos a cada dois dias, às 18 horas. Foram realizadas 27 colheitas, sendo colhidos os frutos maiores que 0,15 m. Foram planejadas parcelas com 1, 2, 3 e 6 plantas por fileira. $\mathrm{O}$ índice de heterogeneidade foi estimado pelo método de Smith e o tamanho ótimo de parcela foi estimado através do método da máxima curvatura modificada. A produção de frutos por planta aumentou gradativamente até atingir o máximo em torno da 15 a.colheita. A produção total foi de 3214, 3124, 3928 e 3248 g planta $^{-1}$, respectivamente, para as freqüências de colheita 1, 2, 3 e 4, não havendo diferença significativa entre elas. O índice de heterogeneidade em estufa plástica foi próximo a zero. O uso de parcelas menores aliado a um maior número de repetições beneficiou a precisão experimental. Embora o tamanho ótimo da parcela para a produção total de frutos tenha variado entre uma e sete plantas, conforme a freqüência de colheitas, o uso de parcelas com três plantas por fileira e seis repetições foi o mais adequado, sendo capaz de detectar uma diferença mínima significativa entre tratamentos igual a $76 \%$ da média.
\end{abstract}

Palavras-chave: Cucurbita pepo, precisão experimental, tamanho de parcela, freqüência de colheitas.

(Recebido para publicação em 8 de julho de 2006; aceito em 26 de fevereiro de 2008)

W hen planning experiments, the size and the shape of the experimental plots, as well as the number of replications, are some of the problems frequently faced by the researcher. It is essential that these factors are determined in order to decrease experimental error and maximize data gathered from the experiment (Steel et al., 1997). The same authors report that the plot, the basic unit of an experiment, must be able to reduce to a maximum the effects of environmental heterogeneity, as well as the genetic variability of the experimental material, by means of directly influencing the expense of the available resources to conduct the experiment. Size and shape of the plots can not be generalized because they change according to soil and crop. Plot size and shape must be tailored for each crop and place in which climatic and soil conditions differed from what had been previously defined (Oliveira \& Estefanel, 1995). The increase in plot size leads to the reduction in variance among plots (Rezende \& Souza Júnior,
1997). Nevertheless, this decrease is not proportional to plot size (Le Clerg, 1967) and little gain in accuracy is obtained with the increase in plot size, if they are already large (Resende \& Souza Junior, 1997). Besides it must be considered that smaller plots allow setting a greater number of replications in the same area, resulting in more degrees of freedom in the residue (Zanon \& Storck, 1997). The increase in plot size is more efficient when nearby plots are not correlated. On the other hand, when Smith heterogeneity 
coefficient is next to zero, gains in experimental efficiency by increasing plot size and/or number of replications will be minimum (Lin \& Binns, 1986; Swallow \& Wehner, 1986).

Notwithstanding the importance of the protected cultivation, research results that subsidize the utilization of the potential of such technology on the different climatic regions in Brazil are still insufficient (Lopes Filho, 2000), as well as those results needed to guide the experimental planning (Lopes et al., 1998). Concerning the protected grown crops, Souza (2001), Lúcio et al. (2003), and Lorentz et al. (2005) conclude that the irregularity in the production occurs with greater intensity between cultivation lines. Thus, plots comprising variations on line length (North-South) should be planned, so that to minimize such variations and still to guarantee a reasonable number of treatments and replications to be established.

Commercial vegetable cultivation at plastic greenhouses is a consolidated and growing activity (Medeiros et al., 2001). Zucchini is one of the most popular Cucurbitaceae in Brazil, with yields ranging between 10 and $20 \mathrm{t} \mathrm{ha}^{-1}$ when cultivated at field conditions, and prices varying between $\mathrm{R} \$ 6,00$ and $\mathrm{R} \$$ 14,00 a $20-\mathrm{kg}$ box. Considering that fruits should fit a commercial standard, experimental evaluation, including harvests, are performed along time, resulting in an increase in the labor during the experiment. In addition, a cyclic trend in production is being observed, which can be caused by harvest frequency, creating heterogeneity in yield among harvests.

The objectives of this work were: a) to assess the heterogeneity index at different harvesting frequencies of zucchini grown under protected cultivation, as well as the accumulated fruit weight on every six-day-period; b) to estimate the optimum plot size and c) to determine the least significant difference between treatments as function of the variation in plot size and number of replications.

\section{MATERIAL AND METHODS}

Zucchini seeds, cultivar Caserta, were sown on a polystyrene tray containing 144 cells on August $18^{\text {th }}$, 2003, using Plantmax commercial substrate. Trays were maintained on a greenhouse up to transplanting (September $\left.8^{\text {th }}, 2003\right)$, which was performed when plants presented three leaves. The experiment was carried out on a plastic greenhouse - high tunnel, $20 \times 5$ m (length $x$ width), in an area of the Crop Technology Department, of Santa Maria University, Santa Maria, Rio Grande do Sul State, Brazil. The soil in the area is a Gleyic Phaeozem.

Prior to transplanting, the soil was plowed to form three ridges, which were fertilized with $660 \mathrm{~g}$ of urea, $320 \mathrm{~g}$ of $\mathrm{P}_{2} \mathrm{O}_{5}$, and $150 \mathrm{~g}$ of $\mathrm{K}_{2} \mathrm{O}$ per each $20 \mathrm{~m}$ line. Hoses for drip irrigation were placed on the ridges and covered with $30 \mathrm{~mm}$ black mulch. Staking was introduced on September $22^{\text {nd }}$ and $23^{\text {rd }}$, 2003 and on November $7^{\text {th }}, 2003$, preventive applications of Folicur fungicide ( $5 \mathrm{~mL} 16 \mathrm{~L}^{-1}$ ) and of Orthene insecticide (8 g $16 \mathrm{~L}^{-1}$ ) were carried out.

Space between plants and lines was 0.8 and $1.0 \mathrm{~m}$, respectively, resulting in 24 plants line ${ }^{-1}$. Four plots were defined. For each 18-plant plot (3 rows x 6 plants), one of the four harvest frequencies (treatments) was assigned. Fruits were harvested daily, at 10:00 h (harvest frequency 1 ); at $10: 00$ and 18:00 h (harvest frequency 2); and at 8:00, 10:00, 12:00, 14:00, 16:00, and 18:00 h (harvest frequency 3 ). In harvest frequency 4 , fruits were collected every other day. Fruits up to $15 \mathrm{~cm}$ long from proximal to distal ends were harvested and weighted on a digital scale, with 1-gram accuracy. For data analysis, results obtained in two days on each of the harvest frequencies 1,2 and 3 were summed up to acquire a quantitative magnitude comparable to harvest frequency 4 . The harvest began on October $15^{\text {th }}$ and lasted up to December $7^{\text {th }}, 2003$, resulting in 27 harvests in 54 days.

The analyzed trait was fruit weight plant $^{-1}$ (g) accumulated every six days up to the $\mathrm{n}^{\text {th }}$ harvest $(\mathrm{N})$, that is: $\mathrm{N3}=$ yield up to the third harvest ( $6^{\text {th }}$ day); N6 = yield up to the sixth harvest $\left(12^{\text {th }}\right.$ day); N9 = yield up to the ninth harvest $\left(18^{\text {th }}\right.$ day); N12 = yield up to the $12^{\text {th }}$ harvest ( $24^{\text {th }}$ day); N15 = yield up to the $15^{\text {th }}$ harvest $\left(30^{\text {th }}\right.$ day); N18 = yield up to the $18^{\text {th }}$ harvest (36 ${ }^{\text {th }}$ day); N21 = yield up to the $21^{\text {st }}$ harvest (42 ${ }^{\text {nd }}$ day); N24 = yield up to the $24^{\text {th }}$ harvest (48 ${ }^{\text {th }}$ day); and N27 = yield up to the $27^{\text {th }}$ harvest ( $54^{\text {th }}$ day). The t test, at $5 \%$ probability, was used to compare the means for total fruit weight, on the $27^{\text {th }}$ harvest.

For each harvest frequency, four plot sizes were planned, varying the number of plants in the rows, that is, 1, 2, 3 and 6 plants (Figure 1). The number of replications of each plot size was limited by the total number of plants in each plot (18). To each plot size (x), the following parameters were calculated: $\mathrm{NP}=$ number of plots with $\mathrm{x}$-size basic units (BU); $\mathrm{M}(\mathrm{x})=$ means of plots with $\mathrm{x}$-size $\mathrm{BU} ; \mathrm{V}(\mathrm{x})=$ variance among plots of $\mathrm{x}$ size $\mathrm{BU} ; \mathrm{VU}(\mathrm{x})=\mathrm{V}(\mathrm{x}) / \mathrm{x}^{2}=$ variance per BU among plots of $\mathrm{x}$-size BU; $\mathrm{CV}(\mathrm{x})=$ coefficient of variation among plots of x-size BU (Smith, 1938).

To $\mathrm{n}^{\text {th }}$ harvest and to each harvest frequency, the b heterogeneity index was determined by the Smith (1938) empiric relation $\mathrm{VU}(\mathrm{x})=\mathrm{V}_{1} / \mathrm{X}^{\mathrm{b}}$. The $\mathrm{b}$ value was estimated as a coefficient of linear regression, by means of a logarithmic transformation of the function $\mathrm{VU}(\mathrm{x})=\mathrm{V}_{1} / \mathrm{X}^{\mathrm{b}}$, which estimate was weighted by the degrees of freedom associated to each plot size (Steel et al., 1997). In this model, $V_{1}$ is the parameter to estimate the variance among plots of a BU. Likewise, A and B parameters of the function $\mathrm{CV}(\mathrm{x})=\mathrm{A} / \mathrm{X}^{\mathrm{B}}$, where $\mathrm{A}$ corresponds to the estimate of the $\mathrm{CV}$ for $\mathrm{x}=1 \mathrm{BU}$. The optimum plot size $\chi_{0}$ was estimated by,

$$
\chi_{0}=\exp \left\{\left(\frac{1}{2 B+2}\right) \ln \left[\frac{A^{2} B^{2}(2 B+1)}{B+2}\right]\right\}
$$

which determines the maximum curvature point of $\mathrm{CV}(\mathrm{x})=\mathrm{A} / \mathrm{X}^{\mathrm{B}}$ (Meier \& Lessman, 1971).

To assess treatment (harvest frequency) influence over $\mathrm{X}_{0}$, tests of parallelism (B), same origin (A), and coincidence (A and B) were applied, according to Seber (1976) methodology, on a $5 \%$ probability, due to the fact that if values of $A$ and $B$ in the $X_{0}$ expression are different, they can affect the value of $\mathrm{X}_{0}$. The least significant difference among treatments on percentage of the means (d) was estimated by the 
expression $d=\sqrt{2\left(t_{1}+t_{2}\right)^{2} A^{2} / r \chi_{0}^{b}}$ (Hatheway, 1961), in which $t_{1}$ is the critical value of $t$ of Student to the significance level of $\alpha_{1}(5 \%) ; t_{2}$ is the tabulated value of $t$ of Student obtained from $\alpha_{2}=2(1-p)$, and $p$ is the probability of obtaining significant differences among means (80\%); $\mathrm{A}$ is the estimate of the coefficient of variation among plots of a basic unit (average of four treatments), calculated by the function $\mathrm{CV}(\mathrm{x})=\mathrm{A} / \mathrm{X}^{\mathrm{B}}$ of total yield; $\mathrm{r}$ is the number of replications; $X_{0}$ is the number of basic units per plot; and $b$ is the Smith heterogeneity index. In the greenhouse, the product between $\mathrm{X}_{0}, \mathrm{r}$, and I (number of treatments) is limited to 72 plants and the degrees of freedom are $\mathrm{g} 1=\mathrm{I}(\mathrm{r}-1)$, in a completely randomized experimental design.

To perform the calculation, the following statistical software were used: scientific software NTIA, developed by Technological Center for Informatics (Embrapa, 1997); Office Excel; and a program in the Fortram language (Abou-El-Fittouh et al., 1974) with modifications, which is specific to calculate means and variance of plots of different sizes.

\section{RESULTS AND DISCUSSION}

Fruit yield per plot, during the productive period $\left(\mathrm{M}_{1}\right.$ differences between two consecutive harvests), gradually increased up to a maximum at around the $15^{\text {th }}$ harvest, followed by reduction up to the end of the cycle (Table 1). Total yield was equal to 3214 , 3124, 3928 and 3248 g plant $^{-1}$ to harvest frequencies 1, 2, 3 and 4, respectively, without significant differences at a 5\% probability among them, which indicates that there are no great variations in zucchini productive capacity in the plastic greenhouse. Nevertheless, considering the different harvest frequencies, the $b$ heterogeneity index was higher at frequency 2 from the $18^{\text {th }}$ harvest ahead, probably due to the death of some plants at this harvest frequency.

When the heterogeneity index values are very low, in this case, $b=0.193$, calculated as an average value for the

Table 1. Zucchini accumulated fruit weight up to the $\mathrm{n}^{\text {th }}$ harvest day, heterogeneity index, and optimum plot size, for four harvest frequencies (fitomassa de frutos de abobrinha-italiana acumulada até o n-ésimo dia de colheita, índice de heterogeneidade e tamanho ótimo de parcela, para quatro freqüências de colheita). Santa Maria, UFSM, 2004.

\begin{tabular}{|c|c|c|c|c|c|c|}
\hline $\mathbf{N}^{01}$ & M12 (g plant $\left.{ }^{-1}\right)$ & $\mathbf{V}_{1}{ }^{2}$ & $\mathbf{b}^{3}$ & A & B & $\mathrm{X}_{0}^{4}$ \\
\hline \multicolumn{7}{|c|}{ Daily harvest, 10:00 am } \\
\hline 3 & 323 & 76649.62 & 0.624 & 87.234 & 0.285 & 10.53 \\
\hline 6 & 542 & 106860.63 & 0.249 & 60.340 & 0.098 & 3.87 \\
\hline 9 & 842 & 286645.06 & 0.248 & 64.264 & 0.102 & 4.28 \\
\hline 12 & 1305 & 461852.11 & 0.036 & 51.522 & 0.001 & 1.00 \\
\hline 15 & 2098 & 1070889.32 & 0.055 & 48.512 & 0.038 & 1.32 \\
\hline 18 & 2413 & 1153140.91 & 0.019 & 46.312 & 0.019 & 1.00 \\
\hline 21 & 2668 & 1542631.06 & 0.068 & 43.750 & 0.016 & 1.00 \\
\hline 24 & 2801 & 1578522.75 & 0.141 & 44.373 & 0.056 & 1.77 \\
\hline 27 & 3214 & 2202271.75 & 0.014 & 46.063 & 0.003 & 1.00 \\
\hline \multicolumn{7}{|c|}{ Daily harvest, $10: 00$ and $18: 00 \mathrm{~h}$} \\
\hline 3 & 179 & 33223.08 & 0.173 & 96.362 & 0.109 & 6.51 \\
\hline 6 & 448 & 86163.33 & 0.004 & 67.111 & 0.012 & 1.00 \\
\hline 9 & 761 & 80051.82 & 0.043 & 55.319 & 0.024 & 1.00 \\
\hline 12 & 1212 & 348362.89 & 0.016 & 49.236 & 0.010 & 1.00 \\
\hline 15 & 1995 & 863716.61 & 0.174 & 49.364 & 0.099 & 3.02 \\
\hline 18 & 2432 & 1129177.44 & 0.481 & 45.802 & 0.240 & 5.84 \\
\hline 21 & 2528 & 1199001.88 & 0.425 & 46.026 & 0.218 & 5.54 \\
\hline 24 & 2637 & 1506048.66 & 0.477 & 49.640 & 0.243 & 6.26 \\
\hline 27 & 3124 & 2276159.16 & 0.656 & 51.521 & 0.330 & 7.41 \\
\hline \multicolumn{7}{|c|}{ Daily harvest, $8: 00,10: 00,12: 00,14: 00,16: 00$, and $18: 00 \mathrm{~h}$} \\
\hline 3 & 253 & 62567.42 & 0.888 & 102.391 & 0.428 & 12.84 \\
\hline 6 & 459 & 181861.38 & 0.758 & 93.316 & 0.351 & 11.74 \\
\hline 9 & 1129 & 208650.29 & 0.701 & 124.514 & 0.344 & 14.44 \\
\hline 12 & 1208 & 603801.03 & 0.310 & 65.759 & 0.141 & 5.62 \\
\hline 15 & 2279 & 1242952.31 & 0.018 & 48.618 & 0.012 & 1.00 \\
\hline 18 & 2582 & 1489572.91 & 0.025 & 47.228 & 0.006 & 1.00 \\
\hline 21 & 2993 & 1788700.61 & 0.092 & 44.611 & 0.042 & 1.35 \\
\hline 24 & 3198 & 2094865.69 & 0.087 & 45.015 & 0.039 & 1.26 \\
\hline 27 & 3928 & 912864773.94 & 0.068 & 43.423 & 0.030 & 1.00 \\
\hline \multicolumn{7}{|c|}{ Harvest every other day, 18:00 h } \\
\hline 3 & 391 & 102641.74 & 0.033 & 82.023 & 0.014 & 1.00 \\
\hline 6 & 680 & 195438.29 & 0.252 & 67.153 & 0.134 & 5.51 \\
\hline 9 & 935 & 344207.52 & 0.055 & 65.235 & 0.027 & 1.26 \\
\hline 12 & 1427 & 725778.39 & 0.063 & 61.559 & 0.036 & 1.58 \\
\hline 15 & 2119 & 912551.68 & 0.063 & 45.878 & 0.031 & 1.02 \\
\hline 18 & 2470 & 1296268.09 & 0.035 & 47.512 & 0.012 & 1.00 \\
\hline 21 & 2711 & 1439778.73 & 0.041 & 45.331 & 0.028 & 1.00 \\
\hline 24 & 2925 & 2173827.51 & 0.057 & 52.039 & 0.018 & 1.00 \\
\hline 27 & 3248 & 2975730.16 & 0.033 & 55.092 & 0.010 & 1.00 \\
\hline
\end{tabular}

$1 / \mathrm{N}^{\mathrm{o}}$. = number of harvests (número de colheitas); ${ }^{2} / \mathrm{M}_{1}=$ average fruit weight per plant, accumulated up to the $\mathrm{n}^{\text {th }}$ harvest day (média da fitomassa de frutos por planta, acumulada até o n-ésimo dia de colheita); ${ }^{3} / \mathrm{b}=$ heterogeneity index (índice de heterogeneidade); ${ }^{4} / \mathrm{X}_{0}=$ number of plants per plot ( $\mathrm{n}^{\text {o. }}$ de plantas por parcela)

four harvest frequencies on the $27^{\text {th }}$ harvest, the result is a value of $\mathrm{X}_{0}^{\mathrm{b}}$ very close to the unit for any $\mathrm{X}_{0}$ value in the expression $d=\sqrt{2\left(t_{1}+t_{2}\right)^{2} A^{2} / r \chi_{0}^{b}}$. That leaves as divisor only the number of replications and, the smaller the divisor, the greater the calculated least significant difference among treatments (d). Thus, due to low b values, according to Lin \& Binns (1986), there are no acceptable increases in the experimental 
Table 2. Parameters used to estimate the optimum plot size in zucchini grown under protected cultivation (parâmetros utilizados para a estimativa do tamanho ótimo da parcela em experimentos com abobrinha-italiana, em cultivo protegido). Santa Maria, UFSM, 2004.

\begin{tabular}{|c|c|c|c|c|c|c|c|c|}
\hline \multicolumn{3}{|c|}{$I^{1}=4$} & \multicolumn{3}{|c|}{$11=6$} & \multicolumn{3}{|c|}{$I 1=12$} \\
\hline$X_{0}^{2}$ & $r^{3}$ & $\begin{array}{c}d^{4} \% \text { of the } \\
\text { mean }\end{array}$ & $X_{0}^{2}$ & $r^{3}$ & $\begin{array}{c}\mathbf{d}^{4} \% \text { of the } \\
\text { mean }\end{array}$ & $X_{0}^{2}$ & $r^{3}$ & $\begin{array}{c}\mathbf{d}^{4} \% \text { of the } \\
\text { mean }\end{array}$ \\
\hline 1 & 18 & 47.04 & 1 & 12 & 57.64 & 1 & 6 & 81.62 \\
\hline 2 & 9 & 63.27 & 2 & 6 & 77.63 & 2 & 3 & 110.73 \\
\hline 3 & 6 & 75.94 & 3 & 4 & 93.54 & 3 & 2 & 136.26 \\
\hline 6 & 3 & 109.27 & 4 & 3 & 108.21 & & & \\
\hline & & & 6 & 2 & 140.55 & & & \\
\hline
\end{tabular}

1/ I = number of treatments (número de tratamentos); ${ }^{2} / \mathrm{X}_{0}=$ number of plants per plot (n ${ }^{\mathrm{o}}$ de plantas por parcela); $3 / \mathrm{r}=$ number of replications (número de repetições); ${ }^{4} / \mathrm{d}=$ least significant difference among treatment means (diferença mínima significativa entre médias de tratamentos).

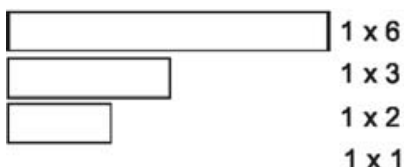

\begin{tabular}{l|l|l|l}
\hline YYYYYY & $Y Y Y Y Y Y$ & $Y Y Y Y Y Y$ & $Y Y Y Y Y Y$ \\
YYYYYY & $Y Y Y Y Y Y$ & $Y Y Y Y Y Y$ & $Y Y Y Y Y Y$ \\
YYYYYY & $Y Y Y Y Y Y$ & $Y Y Y Y Y Y$ & $Y Y Y Y Y Y$ \\
\hline 1 plant
\end{tabular}

Figure 1. Experimental plot sizes used for zucchini production in greenhouse (tamanhos de parcela utilizadas em experimento de produção de abobrinha-italiana em cultivo protegido). Santa Maria, UFSM, 2004.

accuracy with plot enlargement. Values of b closer to zero were also estimated to chemical characteristics on a routine soil analysis, on a survey performed in the same area, before the transplant of zucchini (Feijó et al., 2006). In that circumstance, the estimate of sample size is an important tool to control accuracy when assessing soil chemical characteristics.

On results reported by Alves \& Seraphin (2004), concerning plot sizes and the Smith heterogeneity index, it can be observed that, generally, to a given $\mathrm{CV}$, when the heterogeneity coefficient increases, plot size reduces, and the change in the plot size is more pronounced when the number of replications and the least significant difference to be found are low. Inconsistent results, as those obtained in the present work, can be an effect from the different interpretation of the d expression elements, mainly the value of the coefficient of variation related to the plot of a basic unit (BU) or of the experimental error, and can reach unfeasible and unreal values. The use of the d expression establishes a limit to the available area, that is, the number of available plants to the experimental planning is pre-established.

Values of optimum plot size $\left(\mathrm{X}_{0}\right)$ varied from one plant (one BU) up to the maximum value of 14.4 plants (Table 1). The estimate of the optimum plot size to zucchini cultivated in a plastic greenhouse through the Hatheway (1961) method was defined by Mello et al. (2004) for two different seasons, aiming at least significant difference among treatments of $20 \%$ of the means, using eight replications: in SummerAutumn, the plot size was eight plants (4 x 2, length $x$ width), while during Spring-Winter, the optimum size was four plants.

Different results can be found according to the method used to determine the optimum plot size. On a study to compare the methods to obtain the optimum plot size, Storck et al. (1982) and Viana et al. (2002) concluded that the modified maximum curvature method of Meir \& Lessman (1971) was the most indicated. Thus, excluding the harvest frequency 2, the evaluation of the accumulated yield up to the $15^{\text {th }}$ harvest, about half the productive period, was sufficient to estimate the parameters of the function $\mathrm{CV}(\mathrm{x})=\mathrm{A}$ / $\mathrm{X}^{\mathrm{B}}$ and the optimum plot size (Table 1).
This result is similar to the obtained by Lopes et al. (1998) to tomato cultivated on a plastic greenhouse, in which $1 / 3$ of the initial harvest would be representative of total yield. Accumulated harvests 3, 6, 12, 15, 21, and 24 were parallel and shared the same origin; the $9^{\text {th }}$ accumulated harvest was parallel, but with a different origin; and the accumulated harvests up to the $18^{\text {th }}$ and $27^{\text {th }}$ were not parallel, nor coincident, but had the same origin, indicating differences among $\mathrm{b}$ values and, therefore, not recommended to be used to determine the same plot size for the four harvest frequencies. Limiting the experiment to a total of 72 plants and admitting four treatments $(\mathrm{I}=4)$, 1plant plots $\left(\mathrm{X}_{0}=1\right)$, and 18 replications $(\mathrm{r}=18)$, a minimum significant difference among treatments of $\mathrm{d}=$ $47.0 \%$ was found. This value increases to $\mathrm{d}=109.3 \%$ the experimental plan changes to 6-plant plots, with three replications (Table 2 ).

Concerning the estimated accuracy values (d) (Table 2), if $100 \%$ is adopted as the least significant difference among treatments, the experimental plan to four treatments inside the greenhouse can vary from 1- to 3-plant plots, using from 18 to 6 replications. Fixing as a maximum limit $d=100 \%$, many experimental plans can be used. Among them, 3-plant plots with six replications was the most adequate ( $d=75.9 \%$ ), mainly due to the economy in the number of replications. As the number of treatments increase, the number of replications reduces, with a smaller $\mathrm{X}_{0}$ size. When $\mathrm{X}_{0}$ increases, accuracy is reduced mainly due to the lower number of replications, because b heterogeneity index, assumed as a potency of $\mathrm{X}_{0}$, has little efficiency in reducing the $\mathrm{d}$ value.

\section{REFERENCES}

ABOU-EL-FITTOUH HA; EL-BAKRY AE; ELSERGANY DZ. 1974. A program for studying the optimum plot size in field experiments on the computer. Agricultural Research Review 52: 85-90.

ALVES SMF; SERAPHIN JC. 2004. Coeficiente de heterogeneidade do solo e tamanho de parcela. Pesquisa Agropecuária Brasileira 39: 105-111.

EMBRAPA 1997. Ambiente de software NTIA, versão 4.2.2: manual do usuário - ferramental estatístico. Campinas: Centro Nacional de Pesquisa Tecnológica em Informática para a Agricultura. 258p. 
FEIJÓ S; STORCK L; LÚCIO AD; LOPES SJ. 2006. Heterogeneidade do solo e de tamanho de amostra antes e após cultivos com abobrinha italiana em estufa plástica. Ciência Rural 36: 1744-1748.

HATHEWAY WH. 1961. Convenient plot size. Agronomy Journal 53: 279-280.

LE CLERG EL. 1967. Significance of experimental design in plant breeding. In: FREY KJ (Ed.) Plant breeding symposium. Ames: Iowa State University. p. 243-313.

LIN CS; BINNS MR. 1986. Relative efficiency of two randomized block designs having different plot sizes and numbers of replications and plots per block. Agronomy Journal 78: 531-534.

LOPES FILHO RP. 2000. Utilização de diferentes tanques evaporimétricos em ambiente protegido. Lavras: UFLA. 79f. (Tese mestrado).

LOPES SJ; STORCK L; HELDWEIN AB; FEIJÓ S; ROS CA. 1998. Técnicas experimentais para tomateiro tipo salada sob estufas plásticas. Ciência Rural 28: 193-197.

LORENTZ LH; LÚCIO AD; BOLIGON AA; LOPES SJ; STORCK L. 2005. Variabilidade da produção de frutos de pimentão em estufa plástica. Ciência Rural 35: 316-323.
LÚCIO AD; SOUZA MF; HELDWIN AB; LIEBERKNECHT D; CARPES RH; CARVALHO MP. 2003. Tamanho de amostra e método de amostragem para avaliação de características do pimentão em estufa plástica. Horticultura Brasileira 21: 180-184.

MEDEIROS LAM; MANFRON PA; MEDEIROS SLP; BONNECARRERE RAG. 2001. Crescimento e desenvolvimento da alface (Lactuca sativa L.) conduzida em ambiente protegido plástico com fertirrigação em substratos. Ciência Rural 31: 199-204.

MEIER VD; LESSMAN KJ. 1971. Estimation of optimum field plot shape and size for testing yield in Crambe abyssinica Hochst. Crop Science 11: 648-650.

MELLO RM; LUCIO AD; STORCK L; LORENTZ LH; CARPES RH; BOLIGON AA. 2004. Size and form of plots for the culture of the Italian pumpkin in plastic greenhouse. Scientia Agricola 61: 457-461.

OLIVEIRA PH; ESTEFAEL V. 1995. Tamanho e forma ótimos da parcela para avaliação do rendimento em experimentos com batata. Ciência Rural 25: 205-208.

RESENDE MDV; SOUJA JÚNIOR CL. 1997. Número de repetições e tamanho de parcela para seleção de progênies de milho em solos sob cerrado e fértil. Pesquisa Agropecuária Brasileira 32: 781-788.
SEBER GAF. 1976. Linear regression analysis. New York: John Wiley \& Sons. 465p.

SMITH HF. 1938. An empirical law describing heterogeneity in the yields of agricultural crops. Journal of Agricultural Science 28: 1-23.

SOUZA MF. 2001. Estimativa do tamanho da amostra para culturas olerícolas em ambientes protegidos. Santa Maria: UFSM, 62f. (Tese mestrado).

STEEL RGD; TORRIE JH; DICKEY D. 1997. Principles and procedures of statistics: a biometrical approach. 3th. ed. Boston: WCB/ McGraw Hill. 666p.

STORCK L; SACCOL AV; SCHNEIDER FM. 1982. Comparação de métodos de estimativa do índice de heterogeneidade do solo e do tamanho ótimo de parcela em experimento com soja. Revista Centro de Ciências Rurais 12: 189-202.

SWALLOW WH; WEHNER TC. 1986. Optimum plot size determination and its application to cucumber yield trials. Euphytica 35: 421-432.

VIANAAE; SEDIYAMA T; CECON PR; LOPES SC; SEDIYAMA MAN. 2002. Estimativas de tamanho de parcela em experimentos com mandioca. Horticultura Brasileira 20: 58-63.

ZANON MLB; STORCK L. 1997. Tamanho de parcelas experimentais para Eucalyptus saligna Smith. Ciência Rural 27: 589-593. 